\title{
SOLAR HEAT EFFECTS ON THE DIFFERENT STAGES OF COWPEA BEETLE CALLOSOBRUCHUS MACULATUS(F.)
}

\author{
GHARIB, M. $S^{1}$. AND F. A. EL- LAKWAH ${ }^{2}$ \\ 1. Plant Protection Research Institute, ARC, Dokki, Giza \\ 2. Plant Protection Dept., Fac. of Agric. at Moshtohor, Benha Univ.
}

(Manuscript received 29 April 2009)

\begin{abstract}
Cowpea seeds are one of the main sources of human dietary proteins, planted and harvested in summer and vulnerable to storage infestation by Callosobruchus maculatus (F.). Sunning was tried as possible and safe control method of stored cowpea seeds after harvest from $C$. maculatus infestation. The biological effects of direct solar heat on the different stages (eggs, first-instar larvae, two-week old larvae, newly formed pupae and adults) were studied when exposed these stages for 6 hours daily along 4-5 consecutive days in cowpea seeds which the day temperature ranged from 3238 degree $\mathrm{C}$ with a mean of 35 degree $\mathrm{C}$. Effectiveness was variable with insect stage and duration of sun exposure. Eggs were the most susceptible stage to solar heat followed by first instar larvae while last instar larval instar and the pupal stages were the most resistant stage. A significant reduction of both eggs hatch and its penetration ratio (14.4\%) and adult emergence when eggs (1-2 days old) exposed six hours for four consecutive days. Exposing newly hatched larvae, also leads to a reduction in adult emergence as compared to control. Adult oviposition, mortality and progeny produced also decreased with increase of the exposure period. Percentage of reduction in adult emergence (Inhibition rate, IR \%) increased with increasing of the exposure period. Sunning thus gave good effects by reducing infestation rates and could suppress insect attack by killing eggs and newly formed stages.
\end{abstract}

\section{INTRODUCTION}

Cowpea seeds are considered one of the most important source of dietary proteins for low-income people and widely distributed in many tropical and subtropical regions. Seeds are infested by $C$. maculatus (F.) which make the seeds unsuitable for human consumption. The amount of annual loss reached $24 \%$ of stored pulses from C. maculatus and C. chinensis infestation (Caswell, 1968, and Lale, 1992) within a very short period and complete infestation occur within 3-5 months under traditional storage conditions (Caswell and Akibu, 1980). Reduction of these bruchids by chemicals arisen many undesirable effects as danger of misuse by illiterated farmers, residue hazards in treated seeds as well as development of resistant strains to insecticides. The previous problems led to search for other safe cheap, locally available alternatives. Solarization method is one of the great potential methods for insect management in the Nigerian Savana and other tropical countries where there is 
abundant sunshine throughout the year. The solar heating was investigated for disinfesting of cowpea seeds infested by $C$. maculatus and $C$. chinensis in different countries as Nigeria (Lale and Vidal, 2003). The heat from the sun tends to drive out adult insects, kills the eggs and possibly the early stage larvae depending on the available temperature and periods of sun exposure (Chinwad and Giga, 1996). Utilization of solar heat for bruchid control is based on that insects die when exposed to high temperatures because of their limited physiological capacity to thermoregulate (Murdock and Shade, 1991, Kitch et al., 1992, Murdocks et al., 1997 and Lale, 1998). This study investigates sunning heat effects under Egyptian conditions for possible disinfesting of cowpea seeds from artificial infestation by $C$. maculatus by determining some biological characters of the different stages of this insect when exposed to sun for various periods.

\section{MATERIALS AND METHODS}

C. maculatus was reared for several generations at Stored Grain Insect's Laboratory, Plant Protection Research Institute, on cowpea seeds at $28 \pm 1 \mathrm{C}$ and $65 \pm 5$ $\% \mathrm{RH}$. Seeds were purchased from the local markets and sterilized by deep freezing, to free the seeds from any possible hidden infestation before use (Giga and Smith, 1987).

Insect stages were prepared as follows, about one kilogram of cowpea seeds were infested with about 500 adults of newly emerged for one day and then removed. Many replicates of Petri dishes, each contained about 25 seeds infested with eggs, and exposed to the sun for various exposure periods (3h, 1, 2, 3, 4 and 5 days).

Effects of solar heat were tested on 2-days old eggs as a mid dormant developmental stage which exposed to the sun in replicates of 25 seeds within clear Petri dishes. All the dishes were exposed to the sun in one time, and five dishes were withdraw daily and incubated for two weeks until determining the eggs state and reincubated again until adult emergence start to appear, separated and counted as well as mean developmental period was recorded. The percentage of adult emergence (\%) was determined from the total number of emerged adults compared with the total number of hatched eggs and penetrated larvae, as follows:

$$
\text { Adult emergence }(\%)=\frac{\text { Total emerged adults }}{\text { Total hatched and penetrated eggs }}
$$

Also, the reduction of the adult emergence (\%) as the inhibition rate (IR \%) was also calculated as an indication of the amount of the protection afforded compared to number of newly emerged adults in control and number of newly emerged adults in treatment: 
To study sun heat effects on bruchid larvae (newly hatched larvae and two weeks old larvae) were selected to be exposed to direct sunlight. Infested seeds by both tested instar larvae were assumed to contain newly hatched larvae after four days of seed infestation while after two weeks were presumed to contain two- week's old larvae which the latter was considered as the most active feeding stage. The larvaecontaining seeds were exposed to direct sunlight in replicates of 25 seeds for 1, 2, 3, and 4 and 5 successive days. Control dishes were prepared in the same period and left under open summer conditions without sun exposure. The emerged population were also counted and removed. After 2 days of appearing the future emergence windows seeds were considered to contain the bruchid pupae and at this stage, seeds were exposed to the sunlight for a similar exposure periods as before. The parameters measured were progeny number, adult emergence and reduction (\%) compared to control.

To assay efficacy of solar heat on female oviposition by confining two newly emerged adult pairs in $9.0 \mathrm{~cm}$ Petri dishes with 25 seeds of cowpea and soon covered. Many similar units were done in one time as replicates. All the replicates were exposed to direct sun 6 hours daily within the daytime period of 10.0 am to $4.0 \mathrm{pm}$ for $4-5$ consecutive days which the day temperature ranged from 32-38 degree $C$ with a mean of 35 degree $C$. Three dishes were withdrawn each day at the end of the exposure period and placed under shade in open condition room. The parent mortality (\%) was recorded after 5 days and the left live adults were removed after that. After two weeks, all the replicates were examined for counting number of hatched and unhatched eggs (oviposition). Hatched eggs were defined by the presence of the larval frass, which causes the egg to turn milky white as neonate larvae bore into the seed, while the unhatched eggs remains transparent and glossy (Giga and Smith, 1987). Eggs with clear hatched larvae and seen died within its shells were considered as unhatched eggs. Thus the total numbers of white and translucent eggs on the seeds indicate bruchid oviposition while numbers of white eggs indicate the number of larvae entering the seed (Dharmasena et al., 2001). The obtained data were statistically analyzed using the analysis of variance (ANOVA). Means separation was conducted using Duncan multiple range test (Duncan, 1956) at $0.05 \%$ probability level using a computer program. Standard error was also calculated.

\section{RESULTS AND DISCUSSION}

The effects of solar heat on C. maculatus stages were shown on Tables 1-5. Results showed that the efficacy was depended on the insect stage, and periods of sun exposure, where the efficacy increased with the increase among eggs hatch and larval 
penetration (\%), adult emergence (\%), reduction of adult rate. In respect to effects on C. maculatus eggs (Table 1), great significant differences were observed on the adult emergence, while the other characters as mean developmental period (MDP, days) was not differed significantly. The percentage of larval penetration reduced to $14.4 \%$ for eggs exposed to 4 - day's period compared to $62.2 \%$ of eggs exposed to only one day. Those larvae that hatched and died within egg shell was considered as killed. Progeny number and adult emergence were decreased by increasing periods of exposure to the sun. Reduction of adult emergence (\%) reached $72 \%$ after 4 days. The latter character represents the amount of protection afforded by sunning and increased by increasing the exposure period. It was evident that eggs were the most sensitive to solar heat which kill even the newly hatched larvae within its shells and before its penetration inside the seed. Data in Table 2 showed sunning effects on the newly hatched larvae which showed significant differences were found in adult emergence (\%) which was 41.8 compared to $54.4 \%$. The reduction of adult emergence was also reduced to $22.0 \%$ compared to the control for 4-days exposed newly hatched larvae.

Table 1. Effects of solar heat on 1- 2 days old eggs of Callosobruchus maculatus, exposed 6 hours daily on cowpea seeds.

\begin{tabular}{|l|c|c|c|c|c|c|c|c|}
\hline $\begin{array}{c}\text { Time } \\
\text { (days) }\end{array}$ & $\begin{array}{c}\text { HP } \\
\text { Eggs }\end{array}$ & $\begin{array}{c}\text { UH } \\
\text { Eggs }\end{array}$ & Total & $\begin{array}{c}\text { Larval } \\
\text { Penetration } \\
(\%)\end{array}$ & $\begin{array}{c}\text { MDP } \\
\text { (days) }\end{array}$ & $\begin{array}{c}\text { Progeny } \\
\text { No. }\end{array}$ & $\begin{array}{c}\text { Adult } \\
\text { Emrg (\%) }\end{array}$ & $\begin{array}{c}\text { Reduction } \\
(\%)\end{array}$ \\
\hline 3 Hours & $36.3 \pm 3.5 \mathrm{a}$ & $21.3 \pm 2.5 \mathrm{~d}$ & $57.5 \pm 5.3 \mathrm{~b}$ & $63.25 \pm 2.2 \mathrm{a}$ & $22.0 \pm 0.0 \mathrm{c}$ & $25.3 \pm 3.4 \mathrm{ab}$ & $44.2 \pm 5.3 \mathrm{ab}$ & $18.3 \pm 2.6 \mathrm{c}$ \\
\hline 1 & $33.8 \pm 3.4 \mathrm{ab}$ & $26.5 \pm 2.7 \mathrm{~d}$ & $60.3 \pm 4.1 \mathrm{~b}$ & $56 \pm 3.9 \mathrm{a}$ & $22.8 \pm 0.3 \mathrm{~b}$ & $28.8 \pm 3.3 \mathrm{a}$ & $47.8 \pm 4.6 \mathrm{a}$ & $12.3+5.9 \mathrm{c}$ \\
\hline 2 & $25.8 \pm 0.8 \mathrm{~b}$ & $35.8 \pm 2.3 \mathrm{c}$ & $61.5 \pm 2.5 \mathrm{~b}$ & $41.3 \pm 5.0 \mathrm{~b}$ & $23.3 \pm .3 \mathrm{~b}$ & $18.8 \pm 5.2 \mathrm{bc}$ & $29.7 \pm 7.3 \mathrm{bc}$ & $44.5 \pm 5.6 \mathrm{~b}$ \\
\hline 3 & $14.5 \pm 1.3 \mathrm{c}$ & $45.0 \pm 3.1 \mathrm{~b}$ & $59.5 \pm 4.2 \mathrm{~b}$ & $24.3 \pm 1.2 \mathrm{c}$ & $24.8 \pm 0.3 \mathrm{a}$ & $14 \pm 1.8 \mathrm{c}$ & $23.4 \pm 1.8 \mathrm{c}$ & $56.3 \pm 3.3 \mathrm{ab}$ \\
\hline 4 & $11.3 \pm 1.1 \mathrm{c}$ & $67.3 \pm 4.3 \mathrm{a}$ & $78.5 \pm 4.9 \mathrm{a}$ & $14.35 \pm 1.2 \mathrm{c}$ & $25.0 \pm 0.0 \mathrm{a}$ & $11.5 \pm 1.3 \mathrm{c}$ & $15.0 \pm 1.6 \mathrm{c}$ & $72.0 \pm 30 \mathrm{a}$ \\
\hline Control & $37.5 \pm 0.8 \mathrm{a}$ & $23.2 \pm 2.9 \mathrm{~d}$ & $60.7 \pm 3.5 \mathrm{~b}$ & $62.2 \pm 3.8 \mathrm{a}$ & $22.0 \pm 0.3 \mathrm{c}$ & $31.5 \pm 2.0 \mathrm{a}$ & $53.4 \pm 6.0 \mathrm{a}$ & $11.05 \pm 4.3 \mathrm{c}$ \\
\hline
\end{tabular}

$\mathrm{HP}=$ Hatched and penetrated eggs, $\mathrm{UH}=$ Unhatched and killed eggs, MDP=Mean growth period (in days).

Table 2. Effect of solar heat on newly hatched larvae of C.maculatus infesting cowpea seeds (exposed 6 hours daily).

\begin{tabular}{|c|c|c|c|c|c|c|c|c|}
\hline $\begin{array}{c}\text { Exposure } \\
\text { time } \\
\text { (days) }\end{array}$ & Eggs & UH & Total & $\begin{array}{c}\text { Penetration } \\
(\%)\end{array}$ & $\begin{array}{c}\text { MDP } \\
\text { (days) }\end{array}$ & $\begin{array}{c}\text { Progeny } \\
\text { No. }\end{array}$ & $\begin{array}{c}\text { Adult } \\
\text { Emrg(\%) }\end{array}$ & $\begin{array}{c}\text { Reduction } \\
(\%)\end{array}$ \\
\hline 1 & $33.4 \pm 3.5 \mathrm{a}$ & $24.4 \pm 1.6 \mathrm{ab}$ & $57.8 \pm 3.7 \mathrm{a}$ & $57.3 \pm 3.1 \mathrm{a}$ & $21.8 \pm 0.2 \mathrm{a}$ & $33.6 \pm 3.3 \mathrm{a}$ & $57.6 \pm 3.1 \mathrm{a}$ & $2.9 \pm 0.8 \mathrm{a}$ \\
\hline 2 & $42.4 \pm 6.9 \mathrm{a}$ & $23.4 \pm 1.8 \mathrm{ab}$ & $65.8 \pm 6.7 \mathrm{a}$ & $63.1 \pm 3.9 \mathrm{a}$ & $22.0 \pm 0.0 \mathrm{a}$ & $28.4 \pm 4.6 \mathrm{a}$ & $43.8 \pm 5.7 \mathrm{ab}$ & $20.0 \pm 5.8 \mathrm{a}$ \\
\hline 3 & $34.4 \pm 1.8 \mathrm{a}$ & $21.6 \pm 2.8 \mathrm{~b}$ & $56.0 \pm 2.8 \mathrm{a}$ & $61.8 \pm 3.6 \mathrm{a}$ & $22.0 \pm 0.0 \mathrm{a}$ & $30.0 \pm 1.7 \mathrm{a}$ & $54.2 \pm 1.1 \mathrm{ab}$ & $22.0 \pm 0.4 \mathrm{a}$ \\
\hline 4 & $31.8 \pm 2.8 \mathrm{a}$ & $30.0 \pm 3.0 \mathrm{a}$ & $61.8 \pm 3.6 \mathrm{a}$ & $51.6 \pm 3.4 \mathrm{a}$ & $22.0 \pm 0.0 \mathrm{a}$ & $25.6 \pm 3.3 \mathrm{a}$ & $41.8 \pm 5.1 \mathrm{~b}$ & $21.9 \pm 9.5 \mathrm{a}$ \\
\hline Control & $37.5 \pm 0.8 \mathrm{a}$ & $23.2 \pm 3.0 \mathrm{ab}$ & $60.7 \pm 3.5 \mathrm{aa}$ & $62.2 \pm 3.8 \mathrm{a}$ & $22 \pm 0.0 \mathrm{a}$ & $31.5 \pm 3.0 \mathrm{a}$ & $53.4 \pm 6.0 \mathrm{ab}$ & $11.1 \pm 4.3 \mathrm{a}$ \\
\hline
\end{tabular}

$\mathrm{H} \& \mathrm{P}=$ hatched and penetrated eggs, $\mathrm{UH}=$ Unhatched and killed eggs, $\mathrm{MDP}=$ Mean developmental period (in days). 
Data in Table 3 showed sunning effects on the 2-weeks old larvae which no significant differences were found among the tested biological characters compared to the control. This indicated that this stage was much resistant to solar heat. Data in Table 4 showed sunning effects 1-2days old pupae which significant differences were found only in adult emergence (\%) and reduction of adult emergence compared to control. it was $53.4 \%$ in control compared to $50 \%$ for treatment of four days of sunning. The reduction of adult emergence was also reduced to $26.7 \%$ compared to the control $(11.1 \%)$ for treated pupae.

Table 3. Effects of solar heat on two- week's old larvae of C.maculatus infesting cowpea seeds when exposed 6 hours daily.

\begin{tabular}{|c|c|c|c|c|c|c|c|c|}
\hline $\begin{array}{c}\text { Exposure } \\
\text { time } \\
\text { (days) }\end{array}$ & Eg & UH & Total & $\begin{array}{c}\text { Penetration } \\
(\%)\end{array}$ & $\begin{array}{c}\text { MDP } \\
\text { (days) }\end{array}$ & $\begin{array}{c}\text { Progeny } \\
\text { No. }\end{array}$ & $\begin{array}{c}\text { \%Adult } \\
\text { Emrg }\end{array}$ & $\begin{array}{c}\text { Reduction } \\
(\%)\end{array}$ \\
\hline 1 & $35.2 \pm 0.8 \mathrm{a}$ & $24.2 \pm 3.9 \mathrm{a}$ & $59.4 \pm 3.1 \mathrm{a}$ & $59.7 \pm 5.2 \mathrm{a}$ & $22.0 \pm 0.0 \mathrm{~b}$ & $26.8 \pm 2.3 \mathrm{a}$ & $45.1 \pm 3.1 \mathrm{a}$ & $15.6 \pm 5.8 \mathrm{a}$ \\
\hline 2 & $33.2 \pm 3.0 \mathrm{a}$ & $23.6 \pm 1.7 \mathrm{a}$ & $56.8 \pm 2.5 \mathrm{a}$ & $58.1 \pm 3.8 \mathrm{a}$ & $22.8 \pm 0.2 \mathrm{a}$ & $29.4 \pm 2.5 \mathrm{a}$ & $51.5 \pm 3.3 \mathrm{a}$ & $6.7 \pm 02.9 \mathrm{a}$ \\
\hline 3 & $35.8 \pm 1.7 \mathrm{a}$ & $21.0 \pm 4.4 \mathrm{a}$ & $56.8 \pm 4.8 \mathrm{a}$ & $64.0 \pm 4.6 \mathrm{a}$ & $23.0 \pm 0.0 \mathrm{a}$ & $29.8 \pm 1.8 \mathrm{a}$ & $49.8 \pm 5.4 \mathrm{a}$ & $11.2 \pm 7.8 \mathrm{a}$ \\
\hline 4 & $38.5 \pm 2.7 \mathrm{a}$ & $19.8 \pm 2.0 \mathrm{a}$ & $58.3 \pm 4.7 \mathrm{a}$ & $66.3 \pm 0.9 \mathrm{a}$ & $22.5 \pm 0.3 \mathrm{ab}$ & $31.0 \pm 1.2 \mathrm{a}$ & $54.3 \pm 2.7 \mathrm{a}$ & $2.7 \pm 0.04 \mathrm{a}$ \\
\hline 5 & $32.7 \pm 1.2 \mathrm{a}$ & $18.3 \pm 0.9 \mathrm{a}$ & $52.3 \pm 2.0 \mathrm{a}$ & $62.6 \pm 3.0 \mathrm{a}$ & $22.3 \pm 0.3 \mathrm{ab}$ & $26.0 \pm 2.0 \mathrm{a}$ & $49.7 \pm 2.3 \mathrm{a}$ & $7.3 \pm 0.9 \mathrm{a}$ \\
\hline Control & $37.5 \pm 2.7 \mathrm{a}$ & $23.2 \pm 3.0 \mathrm{a}$ & $60.7 \pm 3.5 \mathrm{a}$ & $62.2 \pm 3.8 \mathrm{a}$ & $22.0 \pm 0.3 \mathrm{~b}$ & $31.5 \pm 2.0 \mathrm{a}$ & $53.4 \pm 6.0 \mathrm{a}$ & $11.1 \pm 4.3 \mathrm{a}$ \\
\hline
\end{tabular}

$\mathrm{HP}=$ hatched and penetrated eggs, $\mathrm{UH}=$ Unhatched and killed eggs, MDP=Mean developmental period (in days).

Table 4. Effect of solar heat on pupae of C.maculatus infesting cowpea seeds, exposed 6 hours daily.

\begin{tabular}{|l|c|c|c|c|c|c|c|c|}
\hline $\begin{array}{c}\text { Exposure } \\
\text { time } \\
\text { (days) }\end{array}$ & HP & UH & Total & $\begin{array}{c}\text { Lenetration } \\
(\%)\end{array}$ & $\begin{array}{c}\text { MDP } \\
\text { (days) }\end{array}$ & $\begin{array}{c}\text { Progeny } \\
\text { No. }\end{array}$ & $\begin{array}{c}\text { Adult } \\
\text { Emrg (\%) }\end{array}$ & $\begin{array}{c}\text { Reduction } \\
(\%)\end{array}$ \\
\hline 1 & $40.8 \pm 1.5 \mathrm{a}$ & $17.0 \pm 1.8 \mathrm{ab}$ & $57.8 \pm 3.0 \mathrm{a}$ & $69.1 \pm 1.3 \mathrm{a}$ & $22.0 \pm 0.0 \mathrm{a}$ & $30.4 \pm 0.7 \mathrm{a}$ & $52.9 \pm 1.5 \mathrm{a}$ & $3.2 \pm 0.2 \mathrm{~b}$ \\
\hline 2 & $39.6 \pm 2.9 \mathrm{a}$ & $17.8 \pm 1.3 \mathrm{ab}$ & $57.4 \pm 3.8 \mathrm{a}$ & $68.9 \pm 1.5 \mathrm{a}$ & $22.4 \pm 1.9 \mathrm{a}$ & $22.6 \pm 1.9 \mathrm{~b}$ & $39.4 \pm 7.3 \mathrm{a}$ & $26.7 \pm 2.2 \mathrm{a}$ \\
\hline 3 & $34.0 \pm 2.8 \mathrm{a}$ & $15.8 \pm 1.4 \mathrm{~b}$ & $49.8 \pm 2.6 \mathrm{a}$ & $68.0 \pm 3.2 \mathrm{a}$ & $22.6 \pm 0.2 \mathrm{a}$ & $27.0 \pm 3.2 \mathrm{ab}$ & $54.2 \pm 5.7 \mathrm{a}$ & $7.2 \pm 4.2 \mathrm{~b}$ \\
\hline 4 & $35.2 \pm 3.6 \mathrm{a}$ & $17.7 \pm 1.2 \mathrm{ab}$ & $52.3 \pm 3.9 \mathrm{a}$ & $66.6 \pm 2.7 \mathrm{a}$ & $22.3 \pm 0.2 \mathrm{a}$ & $26.0 \pm 1.6 \mathrm{ab}$ & $50.1 \pm 2.1 \mathrm{a}$ & $8.1 \pm 3.2 \mathrm{~b}$ \\
\hline Control & $37.5 \pm 2.7 \mathrm{a}$ & $23.2 \pm 3.0 \mathrm{a}$ & $60.6 \pm 3.5 \mathrm{a}$ & $62.2 \pm 3.8 \mathrm{a}$ & $22.6 \pm 0.3 \mathrm{a}$ & $31.5 \pm 2.0 \mathrm{a}$ & $53.4 \pm 6.0 \mathrm{a}$ & $11.1 \pm 4.3 \mathrm{~b}$ \\
\hline
\end{tabular}

$\mathrm{HP}=$ hatched and penetrated eggs, $\mathrm{UH}=$ Unhatched and killed eggs, MDP=Mean developmental period (in days).

Data in Table 5 showed sunning effects on the adult mortality (\%) and subsequent biological characters as oviposition, larval growth, progeny number and adult emergence (\%). oviposition or the number of laid eggs/ 5 pairs on sun- exposed seeds was reduced from 317.0 eggs in control to 69.3 eggs in treatment. The eggs 
hatch and larval penetration (\%) were also significantly affected compared to the control. It was also observed that the mean duration of development (MDP, days) was not affected compared to control i.e. it was 18.0 days. Percentages of adult emergence and its reduction showed significant differences. Progeny was much reduced to 8.0 adults emerged from the infested seeds compared to 180.4 adult in control. Also adult mortality was much affected (77.5\%) after five days of exposure.

Table 5. Effect of solar heat on oviposition of Callosobruchus maculates infesting cowpea seeds exposed 6 hours daily.

\begin{tabular}{|c|c|c|c|c|c|c|c|c|c|}
\hline $\begin{array}{l}\text { Exposure } \\
\text { time } \\
\text { (days) }\end{array}$ & HP Eggs & $\begin{array}{l}\text { Uh } \\
\text { Eggs }\end{array}$ & $\begin{array}{l}\text { Total } \\
\text { Eggs }\end{array}$ & $\begin{array}{c}\text { Larval } \\
\text { Penetration } \\
(\%) \\
\end{array}$ & $\begin{array}{l}\text { MDP } \\
\text { (days) }\end{array}$ & $\begin{array}{c}\text { Progeny } \\
\text { No. }\end{array}$ & $\begin{array}{c}\text { Adult } \\
\text { Emrg(\%) }\end{array}$ & $\begin{array}{l}\text { Reduction } \\
\qquad(\%)\end{array}$ & $\begin{array}{l}\% \text { Adult } \\
\text { mort/w }\end{array}$ \\
\hline 1 & $149.7 \pm 22.3 b$ & $15.3 \pm 4.3 \mathrm{~b}$ & $165.0 \pm 26.5 b$ & $91.1 \pm 1.2 \mathrm{a}$ & $19.7 \pm 0.9 \mathrm{a}$ & $64.3 \pm 6.7 b$ & $41.7 \pm 9.8 \mathrm{a}$ & $29.4 \pm 5.0 \mathrm{bc}$ & $60.0 \pm 5.7 b$ \\
\hline 3 & $66.0 \pm 6.5 c$ & $41.0 \pm 3.5 b$ & $107.0 \pm 9.3 b c$ & $63.6 \pm 4.7 b$ & $21.0 \pm 0.6 \mathrm{a}$ & $45.0 \pm 6.4 b$ & $47.1 \pm 9.4 \mathrm{a}$ & $23.0 \pm 1.5 b c$ & $90.0 \pm 5.8 a$ \\
\hline 4 & $29.7 \pm 4.2 \mathrm{~cd}$ & $99.7 \pm 7.2 \mathrm{a}$ & $129.3 \pm 2.1 b c$ & $21.5 \pm 9.9 c$ & $21.7 \pm 0.3 a$ & $17.7 \pm 6.1 \mathrm{c}$ & $12.9 \pm 3.8 \mathrm{~b}$ & $77.5 \pm 11.5 a$ & $80.0 \pm 11.5 a b$ \\
\hline 5 & $12.0 \pm 0.9 \mathrm{~d}$ & $57.3 \pm 5.2 \mathrm{ab}$ & $69.3 \pm 3.8 \mathrm{c}$ & $13.8 \pm 7.0 \mathrm{c}$ & $15.3 \pm 3.7 \mathrm{a}$ & $8.0 \pm 2.6 c$ & $9.2 \pm 4.7 b$ & $51.0 \pm 5.1 \mathrm{ab}$ & $90.0 \pm 10.0 \mathrm{a}$ \\
\hline
\end{tabular}

$\mathrm{HP}=$ Hatched and penetrated eggs, $\mathrm{UH}=$ Unhatched and killed eggs, MDP=Mean developmental period (in days).

Some workers have investigated the effect of solar heating of stored pigeonpea seeds as a low cost control method (Chauhan and Ghaffan, 2002) and recommended its use on other legume crops as cowpea while Ntoukam et al., 1997, developed a successful heater technique with a $50-\mathrm{kg}$ capacity to eradicate and kill all developmental insect stages with of $C$. maculatus infested cowpea seeds. Solar heating method eliminated $C$. maculatus infestations and had no significant effect on cowpea germination rates (Paddock and Reinhard, 1999, Murdock and Shade, 1991) even temperature raised to $89 \mathrm{C}$. The solar heat could be a practical and useful method particularly for researchers in developing countries for conserving cowpea germplasm and breeding stocks as well as for farmers holding their small scale productions. The seed moisture content of Sun-dried cowpea seeds is reduced to $1.5 \%$ after a 2-h solar heater treatment and this makes the seed storage more successful. Lale and Maina(2002) reported that no adult progeny of Caryedon serratus developed in groundnut seeds when infested with the different larval instars and exposed to direct solar heat for 6-h. As well, Lale and Vidal (2003) reported no C. maculatus and C. subinnotatus adults developed after exposure to $50 \mathrm{C}$ in seeds harboring first instar larvae when exposed to 2, 4 and 6 hours. These workers found that solarization is cheap, safe and effective method for managing bruchids and weevil populations in 
seeds and cereals in parts of the tropical Africa and Asia (Kitch et al., 1992, Chinwada and Giga, 1996, More et al., 1996, Murdock et al., 1997 and Lale and Ajyayi, 2001). The reduction of oviposition and adult emergence afforded by solarization might due to its effects on both adults and eggs, thus rendering the adults prefer to escape from heated seeds and lay fewer eggs as well as render most of the eggs unviable or dead and so no emerged adults compared to control.

From the present work, varying effects have been found on oviposition, larval growth and adult emergence. Solarization thus could offers a great prospect for successful protection of seed legumes against $C$. maculatus infestations and does not need any extra financial investment in equipment or technical know -how or part of subsistence farmers has been used it successfully. Thus sunning could be easily available in the Egypt as well as easily collected. It had been used by the Egyptian farmers in groundnut pods after harvest to reduce its moisture content and to be safe in storage and thus could be used as protection method of cowpea seeds to reduce this bruchid infestation and avoid the risks associated with the insecticides use.

\section{REFERENCES}

1. Caswell, G. H. 1968. The storage of cowpeas in Northern States of Nigeria. Proceedings of the Agricultural Society of Nigeria, Vol.5, pp. 4-5.

2. Caswell, G. H. and S. Akibu. 1980. The use of Primiphos-methyl to control bruchids attacking selected varieties of stored cowpeas. Trop.Grain Legume Bull., 17/18: 911.

3. Chinwada, P. and D. P. Giga. 1996. Sunning as a technique for disinfesting stored beans. Postharvest Biology and Technology 9, 335-342.

4. Dharmasena, C. M. D., W. M. Blaney and M. S. G. Simmonds. 2001. Effect of storage on the efficacy of powdered leaves of Annona squamosa for the control of Callosobruchus maculatus on cowpeas (Vigna unguiculata). Phytoparasitica, 29(3): $1-6$

5. Giga, D.P. and R. H. Smith. 1987. Egg production and development of Callosobruchus rhodesianus (Pic.) and C. maculatus (F.) (Coleoptera: Bruchidae) on several commodities at two different temperatures. J. Stored Pod. Res. 23: 9 15.

6. Kitch,L.W. G. Ntoukam, R. E.Shade, J. L.Wolfson and I. I. Murdock. 1992. A solar heater for disinfesting stored cowpeas on subsistence farmers. J.Stored Prod.Res., 28(4): 261- 267. 
7. Lale, N.E.S. and F. A. Ajyayi. 2001. Suppression of development of Callosobruchus maculatus (F.) (Coleoptera: Bruchidae) in Bambara groundnut seeds exposed to solar heat in the Nigerian Savanna. Journal of Arid Environments, 40:157- 162.

8. Lale, N. E. S. 1992. Oviposition-deterrent and repellent effects of products from dry chilli pepper fruits, Capsicum species on Callosobruchus maculatus. Postharvest Biology and Technology, 1: 343- 348.

9. Lale, N. E. S. 1998. Preliminary studies on the effect of solar heat on oviposition, development and adult mortality of the cowpea bruchid, Callosobruchus maculates (F.) in the Nigerian Savana. J.Arid Environments, 40, 157- 162.

10. Lale, N. E. S. and Y.T. Maina. 2002. Evaluation of host resistance, solar heat and insecticidal essential oils for the management of Carreydon serratus (Olivier) (Coleoptera: Bruchidae) infesting groundnut seeds and tamariad pods in storage J.PI.Diseases Protect., 109: 410- 420.

11. Lale, N. E. S. and S. Vidal. 2003. Simulation studies on the effects on the solar heat on the egg-laying development and survival of Callosobruchus maculatus (f.) and Callosobruchus subinnotatus (PIC.) in stored bambara groundnuts., Vigna subterranes (I.)Verdcourt. J. Stored Prod.Res.39:447- 58.

12. Murdock, L.L. and R. E. Shade. 1991. Eradication of cowpea weevil (Coleoptera: Bruchidae) in cowpeas by solar heating. American Entomologist, 37:228- 231.

13. More, H. G., P. A.Unde and S. R. Pabalka. 1996. Effects of solar disinfestations on quality os sorghum and storage insect mortality. Journal of Maharashra Agricultural Universities 21, 215- 218.

14. Murdock, L. L., R. E. Shade, L.W. Kitch, W. Noar, O.L.Chambliss, C. Endondo, AND J.L. Wolfson. 1997. Postharvest storageof cowpea in sub-Saharan Africa. Advanes in cowpea Research, IITA and JIRCAS, Ibdan, Nigeria, pp.302- 312.

15. Ntoukam, G., L. W. Kitcg, R. E. Shade and L. L.Murdock. 1997. A novel method for conserving cowpea germplasm and breeding stocks using solar disinfestations. J. Stored Prod.Res.33:175- 179. 


\title{
تاثير حرارة الثمس علي الأطوار الحشرية المختلفة لخنفساء بذور اللوييا
}

\author{
محروس سليمان غريب' فارس أمين اللقوة ‘ \\ ا ـ معرد بحوث وقاية النبات مركز البحوث النراعية - الدقي - جيزة \\ r. . قسم وقاية النبات-كلية الزراعة بمشتهر-جامعة بنها.
}

بذور اللوبيا تمثل أحد المصادر الأساسية للبروتين الغذائي النباتي للإنسان ، ويزرع المحصول

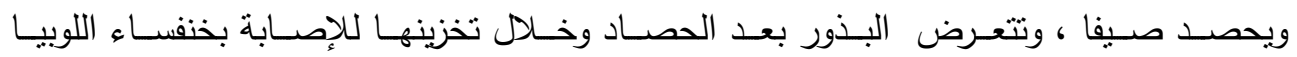
وقد أجريت دراسات أولية تحت الظروف الجوية المفتوحة بمصر Callosobruchus maculatus (F.)

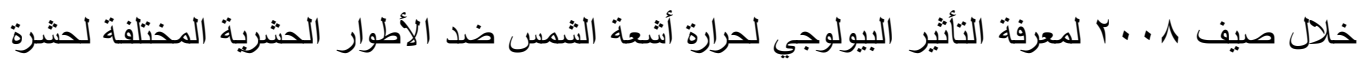
خنفساء اللوبيا وذلك بتعريض البذور المصابة بأطوار الحشرة الأربعة( البيضة- يرقات حديثة الفقس -

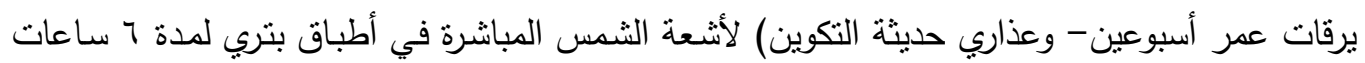

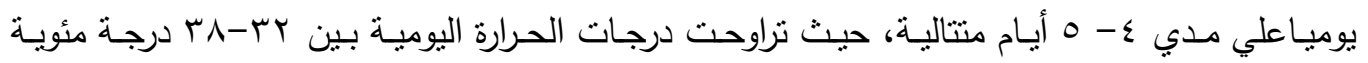
بمتوسط Vr درجة. عند تعريض الحشرات الكاملة لأشعة الشمس المباشرة حدث زيادة في نسبة الموت وإنخفاض عدد

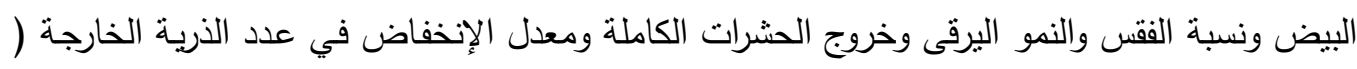
نسبة الحماية الناتجة وصلت وVV مقارنة بالكونترول.

وجد أيضا أن التأثير يعتمد علي الأطوار الحشرية وفترة التعريض للثمس. وكان طور البيض

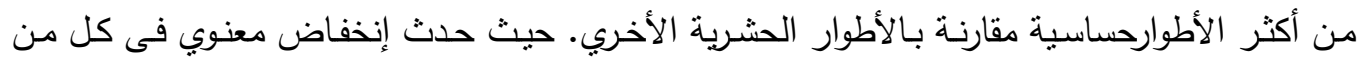

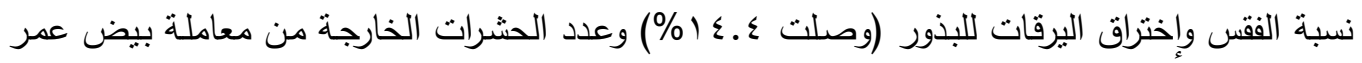
ا- Y يوم بعد أربعة أيام من التعريض.

وعند معاملة اليرقات حديثة الفقس حدث إنخفاض معنوي في نسبة خروج الحشرات الكاملة

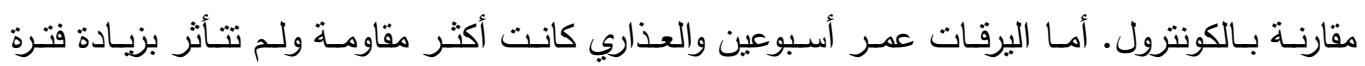

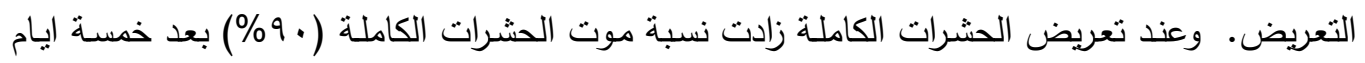

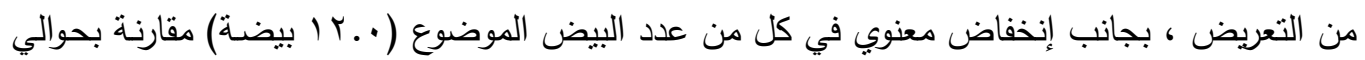
فن . .

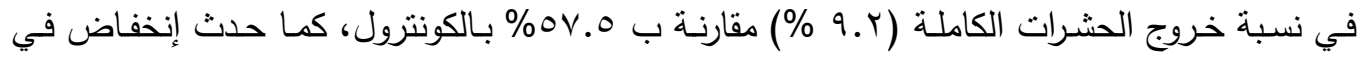
الذرية الناتجة (نسبةالحماية). ويمكن القول أن تعريض بذور اللوبيا لحرارة الثمس توفر حمايـة نسبية

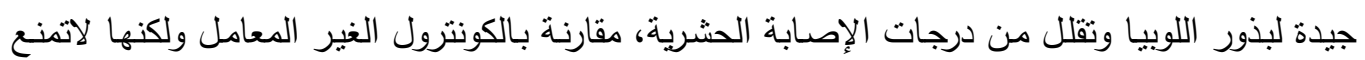

